\title{
ANALISIS SUSEPTIBILITAS MAGNETIK BATUAN PENGEBORAN DI BLOK ELANG SUMBAWA
}

\author{
Romi Aprianto ${ }^{1}$, Kirbani Sri Brtopuspito ${ }^{2}$ \\ 1) Program Studi Pendidikan Fisika FKIP, Universitas Samawa \\ 2) Jurusan Fisika, Fakultas MIPA, Universitas Gadjah Mada \\ Email: Romi231@gmail.com
}

\begin{abstract}
Magnetic susceptibility measurements have been performed in 6 holes hole (ROM-001, ROM-002, ROM-003, ROM-004, ROM-005, dan ROM-006) in Elang, Sumbawa. This study aimed to determine the correlation between magnetic susceptibility in holes. Magnetic measurements were performed using Suceptibility Meter KT-10. Data processing is done by using software Oasis Montaj Drillhole Plotting to analyze correlations and relationships between holes. The interpretation shows that there's correlation between magnetic susceptibility values with intrusion system of phorphyry $\mathrm{Cu}-\mathrm{Au}$. The highest range of magnetic susceptibility value is in Chlorite Sericite Zone (pgm) 0.19x10-3 SI to 1459x10-3 SI. From the magnetic susceptibility values have been estimated position of the intrusion, which is in the ROM 006.
\end{abstract}

Keyword: Magnetic Susceptibility, Magnetic Susceptibility Meter, copper-gold porphyry

\section{Pendahuluan}

Daerah endapan porfiri Cu dan Au Elang Sumbawa terletak di bagian barat daya Pulau Sumbawa dan berjarak kurang lebih $50 \mathrm{~km}$ dari kota Sumbawa, dan $60 \mathrm{~km}$ dari lokasi penambangan Batu Hijau. Daerah Elang merupakan salah satu daerah prospek dari lokasi kontrak karya PT. Newmont dimana wilayahnya mempunyai luas wilayah 94.400 ha. Lokasi dapat ditempuh dengan berjalan kaki dengan waktu tempuh kurang lebih 8 jam dan dengan helikopter 10 menit dimana keadaan lokasi merupakan daerah yang perbukitan hingga pergunungan yang mempunyai ketinggian $300 \mathrm{~m}$ hingga $1000 \mathrm{~m}$ diatas permukaan laut (Lubis, dkk, 2006).

Daerah prospek Elang ditemukan pada tahun 1990 oleh team eksplorasi PT. Newmont, eksplorasi yang dilakukan yang diawali dengan melakukan strean sediment dan pemetaan geologi dan ditemukan sebanyak 36 anomali di daerah elang dan kemudian dilakukan pengeboran dan didasari atas sample batuan ditemukan adanya cebakan $\mathrm{Cu}-\mathrm{Au}$ dengan low grade dan selain itu sample pemboran dangkal tahun 1994 ditemukan kadar $\mathrm{Cu}$ - Au rendah hingga menengah dengan kandungan utama $\mathrm{Cu}-\mathrm{Au}$ (Lubis, dkk, 2006).

Proses eksplorasi yang masih panjang memberikan peluang untuk diperoleh data-data dan informasi yang lebih banyak tentang daerah eksplorasi Elang. Salah satu data yang dibutuhkan dan sangat penting dalam proses eksplorasi ini adalah data suseptibilitas magnetik mineral dan batuan. Suseptibilitas magnetic memiliki kaitan yang erat dengan mineral dan batuan. Setiap mineral dan batuan memiliki nilai suseptibilitas magnetic yang merupakan sifat dan karakter dari batuan dan mineral tersebut. Niai suseptibilitas magnetic sangat bergantung dari unsur-unsur yang menyusun suatu mineral sehingga berdasarkan nilai tersebut dapat diperoleh informasi-informasi mengenai mineral-mineral yang terdapat di dalam lapisan bawah permukaan daerah penelitian.

\section{TinjauAn Pustaka}

Batuan porfiri diinterpretasikan sebagai ubahan silisifikasi dan mengandung tembaga dan emas karena merupakan terusan batuan intrusi (beku) yang telah mengalami proses ubahan silisifikasi. Batuan porfiri mengalami ubahan (alterasi) karena proses urat kuarsa yaitu terkena temperature yang tinggi. Intrusi magma yang terakumulasi di perut gunung api masih memiliki temperature sekitar $700^{\circ} \mathrm{C}$ hingga $1600^{\circ} \mathrm{C}$ dan tekanan yang sangat kuat sehingga terus mendorong ke atas dan menerobos rekahan-rekahan yang akhirnya keluar ke permukaan menjadi lava. Tidak semua magma keluar menjadi lava, bahkan sebagian besar magma tetap tersimpan di perut gunung atau di lempeng benua. Magma tersebut memberikan panasnya kepada batuan yang ditempatinya sehingga mampu mengubah struktur dan sifat-sifat batuan disekitarnya dan 
akhirnya membentuk mineral-mineral yang beraneka ragam. Batuan yang terpengaruh oleh temperature tinggi tersebut dinamakan batuan ubahan (Kahfi dan Yulianto, 2008).

Suseptibilitas magnetik batuan dipengaruhi oleh jenis mineral magnetik dan konsentrasinya di dalam batuan. Adanya nilai yang bervariasi dari pengukuran sampel pada setiap core menandakan adanya berbagai macam mineral magnetik yang terkandung dalam setiap sampel (Jahidin dkk, 2011).

Endapan porfiri $\mathrm{Cu}-\mathrm{Au}$ Elang terletak di selatan Sumbawa di Indonesia sekitar $60 \mathrm{~km}$ sebelah timur tambang Porfiri $\mathrm{Cu}-\mathrm{Au}$ (Gambar 1). Daerah ini adalah endapan yang besar dengan estimasi sumber daya saat ini $1.430 \mathrm{Mt}$ dengan 0,35 g / t Au dan 0,33 g/ t Cu (Ball, 2011).

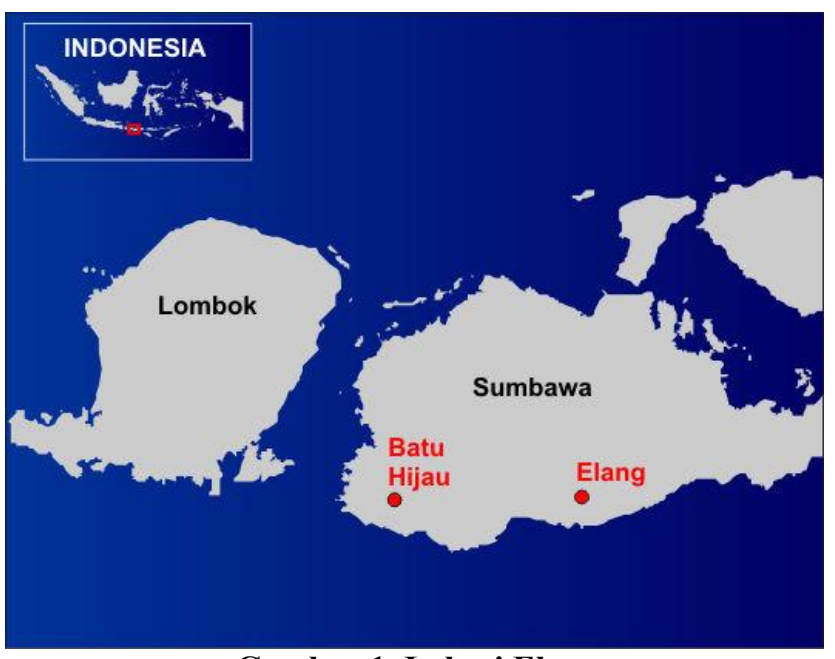

Gambar 1. Lokasi Elang

Kegiatan pengambilan daerah sedimen sungai dan pemetaan di tahun 1987 dan 1988 menghasilkan penemuan urat-urat epitermal di daerah Elang. Setelah beberapa kegiatan pengeboran, di mana tidak ada emas yang signifikan yang terdeteksi, eksplorasi berhenti sampai penemuan Batu Hijau pada tahun 1991. Kemudian daerah Elang ini dipelajari ulang dan ditemukan endapan porfiri $\mathrm{Cu}$ yang besar dengan kadar rendah. Hal ini tidak dianggap bernilai ekonomis pada waktu itu. Eksplorasi lanjutan kemudian dilakukan pada tahun 2002 dan ditemukan sumber di bagian selatan dibawah lithocap dengan ketebalan sekitar 200 m (Hoschke, 2012)

Beberapa penelitan sebelumnya pernah dilakukan di daerah Elang yang menunjukkan adanya indikasi terbentuknya intrusi. Daerah Elang telah disurvei pada tahun 1993 dengan metode Airbone Magnetic. Elang menunjukkan adanya respon magnetik yang sangat tinggi (sekitar $700 \mathrm{nT}$ ) (Gambar 2).

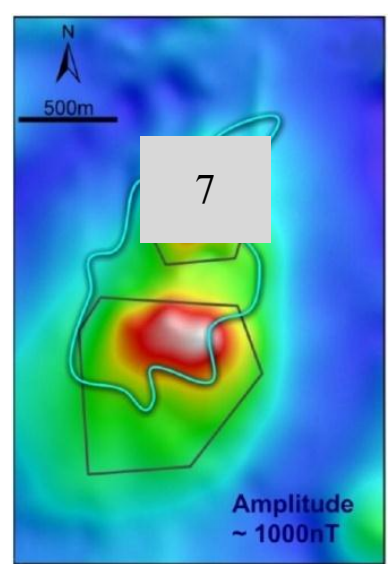

Gambar 2. Airbone Magnetc Elang (Hoschke, 2011)

Survei IP/resistivitas juga telah dilakukan di daerah Elang dengan spasi garis $200 \mathrm{~m}$ dan spasi elektrode 50 $\mathrm{m}$. Terdapat chargeabilitas kuat yang berasosiasi dengan sistem alterasi (Gambar 3).

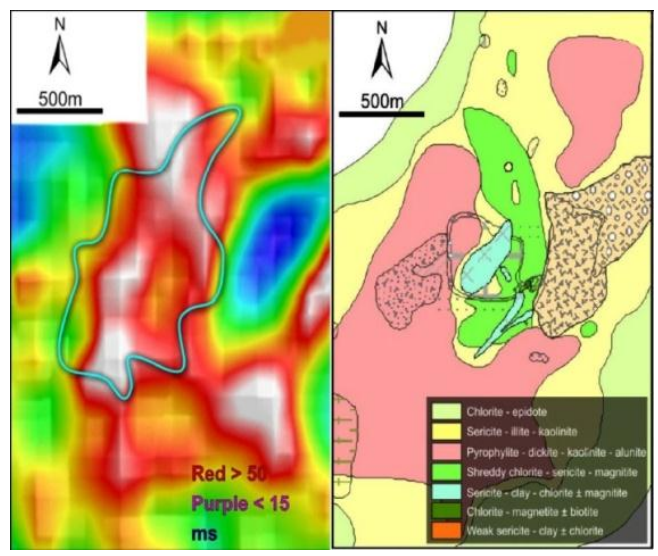

Gambar 3. Chargeabilitas dan Alterasi Elang

(Hoschke, 2012)

\section{A. Suseptibilitas Magnetik}

Ketika tidak ada medan magnet luar, bidang magnetik yang berada dalam batuan, tanah, atau material yang lain akan berorientasi secara acak, disebut zero magnetic field. Namun, ketika material dikenai medan magnet luar seperti medan magnet bumi, bidang magnetik akan berubah mengikuti medan magnet luar, disebut non-zero magnetic field (Gambar 4). 


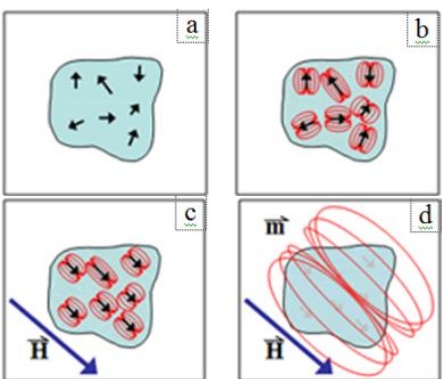

Gambar 4. Kondisi magnetik batuan (a) tidak ada medan magnet luar; (b) domain magnetik terorientasi secara acak; (c) terdapat medan magnet luar; (d) sampel batuan dengan non-zero magnetic field.

Suseptibilitas magnetik adalah ukuran dasar bagaimana sifat kemagnetan suatu bahan yang merupakan sifat magnet bahan yang ditunjukkan dengan adanya respon terhadap induksi medan magnet yang merupakan rasio antara magnetisasi dengan intensitas medan magnet. Persamaan suseptibilitas magnetik dapat ditulis sebagai berikut,

$$
M=\kappa H
$$

dengan $M$ adalah momen dipol magnetik, $H$ adalah intensitas medan magnet, dan $\kappa$ adalah suseptibilitas magnetik.

\section{B. Kemagnetan Bahan}

Dalam batuan, suseptibilitas pada umumnya tergantung pada persen volume magnetik. Mineral ini sering terdapat pada batuan beku dan metamorf, dan hadir setidaknya pada jumlah trace pada sebagian besar sedimen . Gambar 5 menunjukkan rentang suseptibilitas magnetik dan volume magnetit untuk jenis batuan pada umumnya.

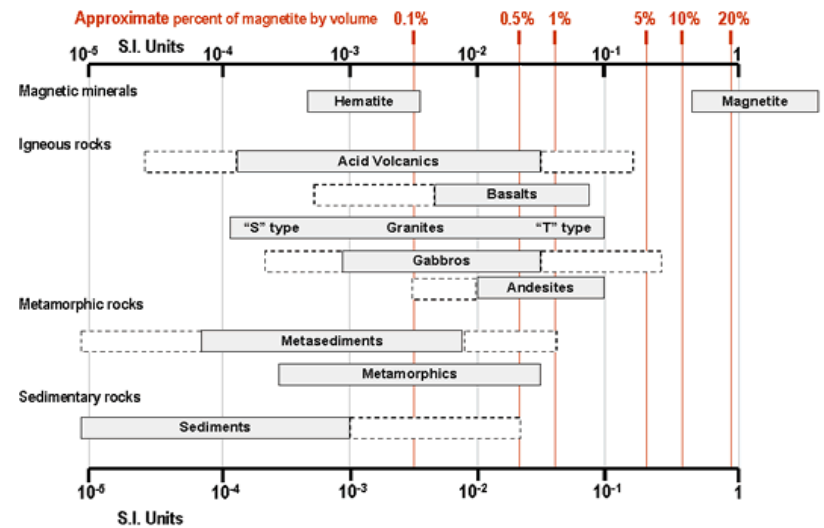

Gambar 5. Suseptibilitas beberapa tipe batuan (Clark dan Emerson, 1991)

\section{Histerisis}

Hysteresis adalah kurva yang menggambarkan sifat bahan magnet dengan membuat plot antara medan magnet luar dan magnetisasi yang terjadi di bahan (Gambar 6).

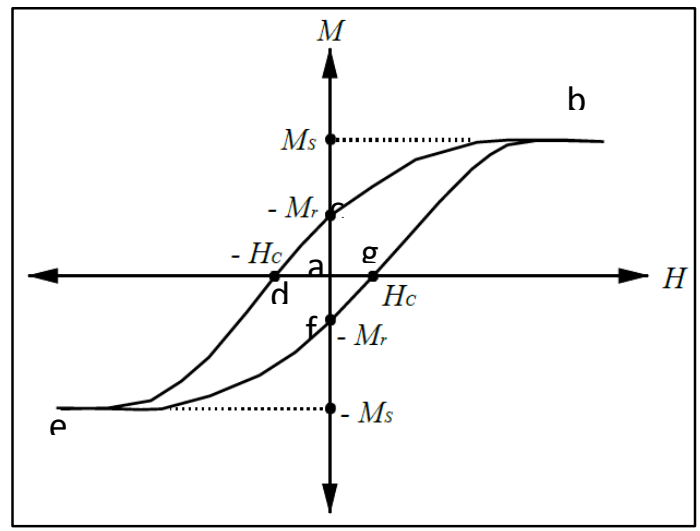

Gambar 6. Kurva Histerisis

Pertama-tama kita anggap sebuah material ferromagnetik yang tidak memiliki magnetisasi (posisi a). Setelah itu material ini kita beri medan magnet luar maka material ini akan mengalami magnetisasi. Setelah beberapa saat maka material ini akan mengalami saturasi (titik b). Pada posisi saturasi ini megnetisasi pada material sudah mencapai tingkat jenuh, material masih bisa mengalami magnetisasi tambahan akan tetapi akan membutuhkan medan magnet luar yang jauh lebih besar. Kurva dari posisi a ke posisi b disebut kurva magnetisasi.

Setelah mencapai posisi b kita turunkan medan magnet luar tadi. Material akan ikut mengalami penurunan magnetisasi, akan tetapi kurva penurunan magnetisasi material tidak akan mengikuti kurva awal, penurunan ini akan membentuk kurva baru yaitu kurva b-c. Setelah semua medan luar dihilangkan material masih memiliki magnetisasi yang tersisa yang bersifat permanen. Magnetisasi permanen yang tersisa setelah semua pengaruh medan magnet luar dihilangkan ini dinamakan magnetisasi remanen (posisi c) disingkat Mr.

Apabila kita turunkan lagi medan magnet luar (maksudnya dibalik) maka magnetisasi remanen ini pada akhirnya akan hilang (posisi d). Medan pembalik luar dimana magnetisasi remanen ini hilang dinamakan koersifitas, diberi simbol Hc. Hasil perkalian dari $\mathrm{Mr}$ (magnetisasi remanen) dan $\mathrm{Hc}$ (koersifitas) ini dinamakan kekuatan dari sebuah magnet. Apabila kita besarkan medan magnet luar ini, material akan termagnetisasi lagi akan tetapi dengan arah yang 
berbeda dengan magnetisasi awal. Material akan mengalami saturasi lagi di posisi e. Kemudian setelah kita turunkan lagi material akan mengalami magnetisai remanen di posisi f dan kemudian koersifitasnya di posisi g. Kurva Hysteresis ini kemudian akan kembali lagi ke posisi a, demikian seterusnya.

\section{Metode Penelitian}

\section{Alat dan Bahan}

Alat yang digunakan dalam penelitan ini adalah Magnetic Susceptibility Meter KT-10 (Gambar 7)

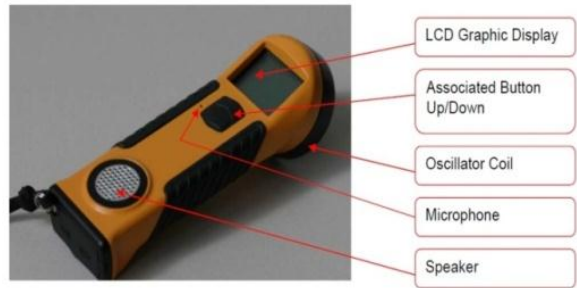

\section{Gambar 7 Magnetic Susceptibility Meter KT-10}

Bahan yang digunakan dalam penelitian ini adalah batuan drill core (Gambar 8) yang diambil dari hasil pengeboran di 6 hole.

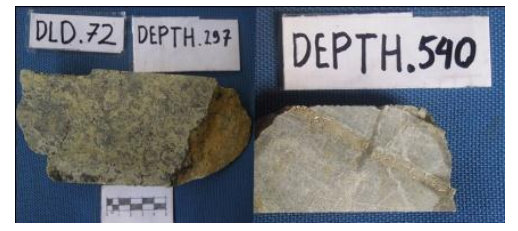

Gambar 8. Core sample

\section{Penentuan titik pengukuran sampel}

Pengukuran dilakukan per interval di tiap hole. Interval ditentukan berdasarkan litologi batuan. Titik pengukuran ditempatkan di bagian atas, tengah, dan bawah sampel core (Gambar 9).

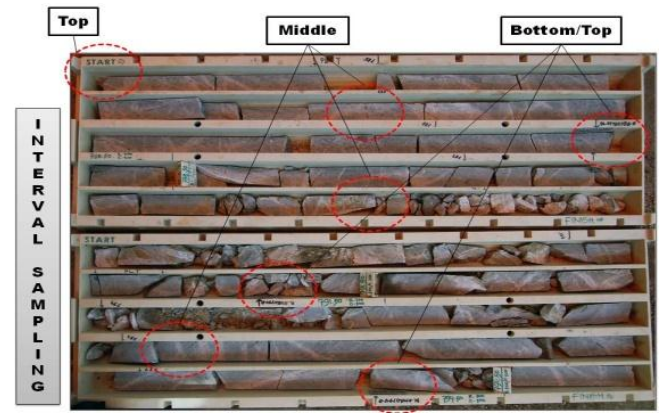

Gambar 9. Titik-titik pengukuran sampel

\section{Akuisisi data}

Secara umum pengambilan data dilakukan dengan langkah-langkah sebagai berikut: a. Setelah dinyalakan, Magnetic Susceptibility Meter KT-10 ditempatkan di udara bebas untuk pengukuran di udara.

b. Setelah terdengar nada tertentu, Magnetic Susceptibility Meter KT-10 ditempatkan di permukaan sampel yang akan diukur nilai suseptibilitas magnetiknya

c. Selanjutnya akan terdengar nada tertentu (yang berbeda dengan nada yang pertama), Magnetic Susceptibility Meter KT-10 ditempatkan lagi di udara bebas

d. Nada yang sama dengan nada yang pertama akan terdengar lagi sebagai tanda pengukuran di titik tersebut telah selesai dilakukan dan pada layar akan terlihat nilai suseptibilitas magnetiknya.

\section{Pengolahan Data}

Penelitian ini menggunakan software Oasis Montaj versi 6.4.2 dalam melakukan pengolahan dan interpretasi.

Saat drilling, geoscientist memperoleh dan mengintegrasikan data dari sumber-sumber dan format yang berbeda, antara lain:

1. Lokasi Drillhole (Data Collar), yang terdiri dari (minimal) Hole ID, Easting, Northing dan Relative Level (Elevasi), azimuth, kemiringan, dan kedalaman.

2. Data Survei, yang terdiri dari Hole ID, kedalaman, azimuth, kemiringan, easting, northing, dan elevasi. Data survey ini hanya dibutuhkan hanya jika hole telah selesai disurvei dan kemiringan dan juga azimuth berubah terhadap kedalaman.

3. Data Assay, yang berisi informasi geokimia batuan.

4. Data Geologi, berisi informasi geologi batuan seperti alterasi, litologi, dan nilai suseptibilitas magnetik batuan. 


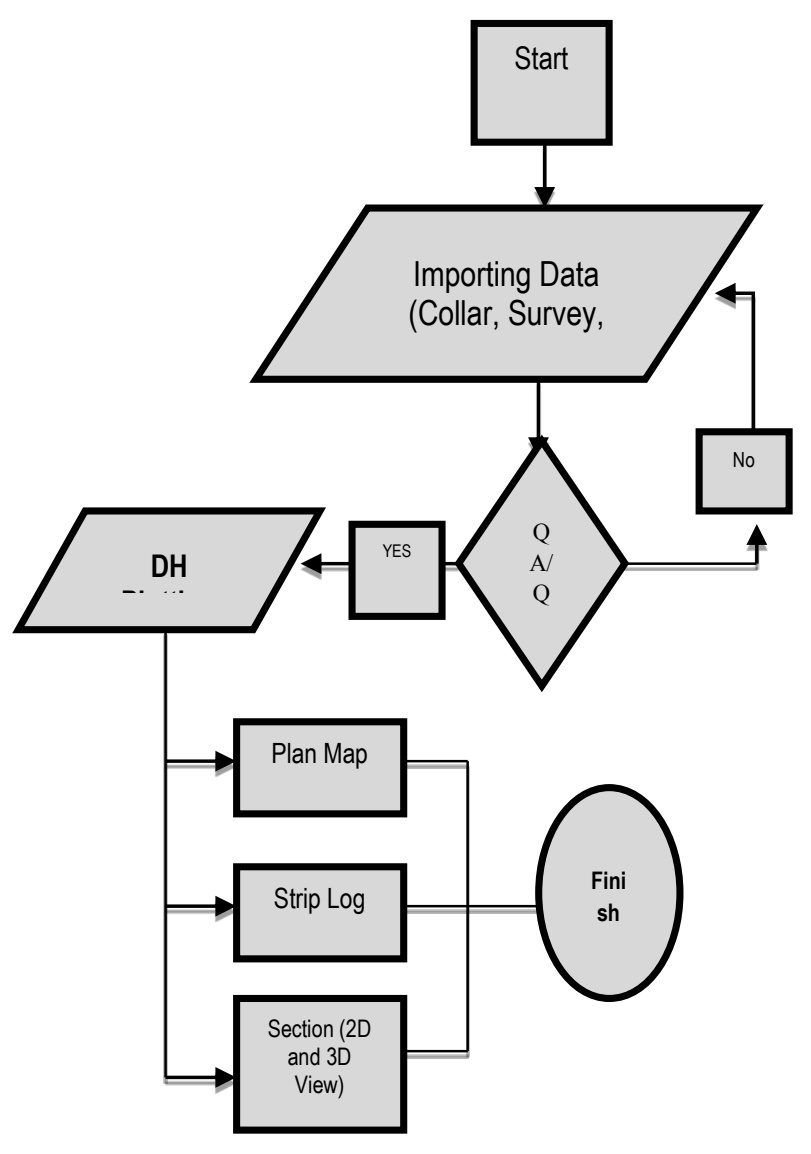

Gambar 11. Diagram alir pengolahan data

Pengolaha data dimulai dengan memasukkan data collar, kemudian dilanjutkan dengan data survei, data assay, dan terakhir data geologi. Setelah semua data dimasukkan, kita dapat melakukan pengecekan kevalidan data dengan fitur QA/QC (Quality Control and Quality Assurance Tests). Jika tidak ada error maka data langsung membuat drillhole plotting dalam tiga bentuk, yaitu plan map, strip log, dan section 2D/3D. (Gambar 11).

\section{Plan Map}

Plan Map berfungsi untuk menunjukkan posisi drillhole dalam arah lateral sehingg dapat ditentukan posisi drillhole yang berada pada satu lintasan, seperti pada Gambar 12.

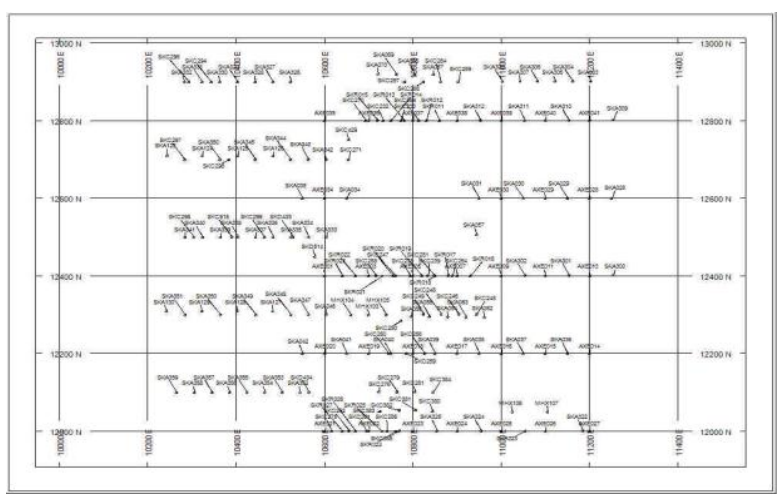

\section{Gambar 12. Plan Map}

\section{Strip Log}

Strip Log bertujuan untuk membuat interpretasi yang memuat informasi tentang perbandingan dan korelasi data di tiap hole, seperti informasi litologi, alterasi, nilai suseptibilitas magnet, dan persentase kandungan mineral-mineral dalam batuan seperti pada Gambar 13.

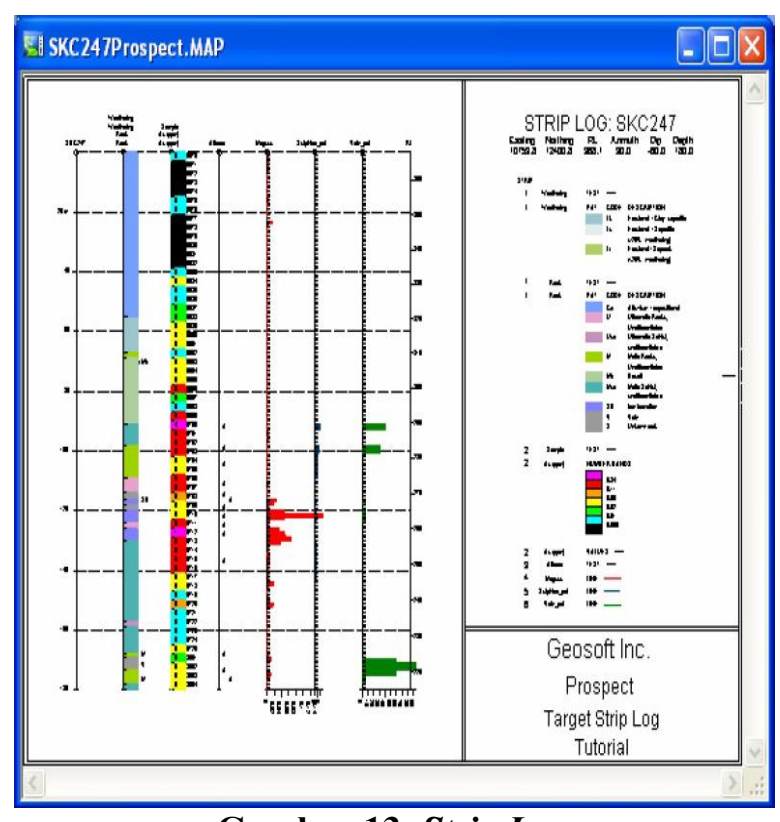

\section{Gambar 13. Strip Log}

\section{$2 D$ dan 3D Section}

Section 2D dan 3D memuat informasi-informasi dari semua hole dalam satu section sehingga kita dapat mengetahui hubungan dan korelasi antar hole dan juga prediksi posisi dari sistem intrusi yang akan dicari (Gambar 14 dan Gambar 15) 


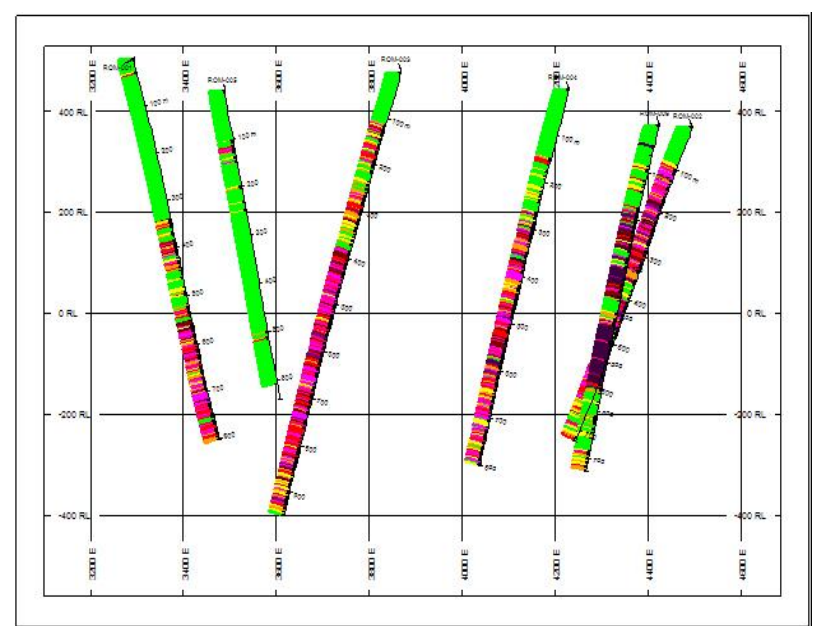

Gambar 14. 2D Section

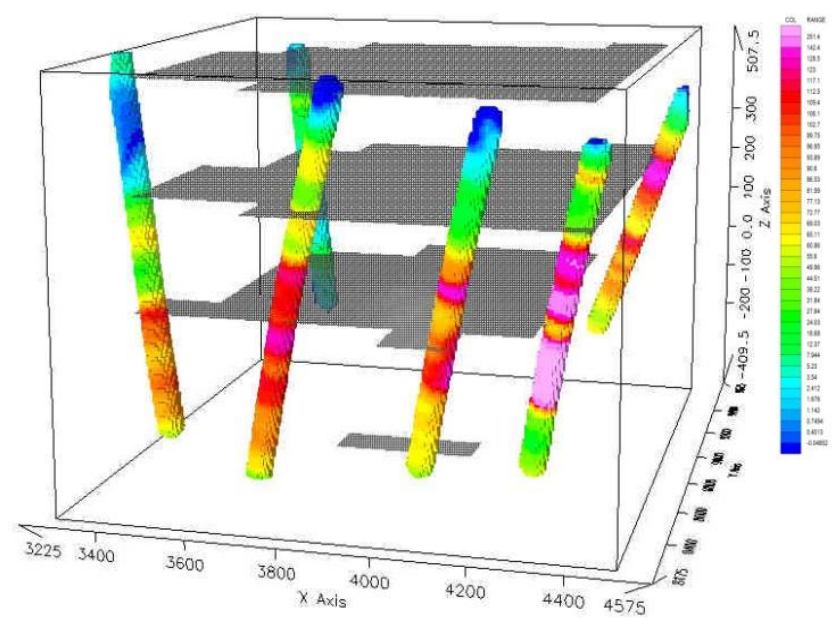

Gambar 15. 3D section

\section{Hasil Dan Pembahasan}

\section{Strip Log}

Strip Log dari 6 hole (ROM-001, ROM-002, ROM003, ROM-004, ROM-005, dan ROM-006) menunjukkan dominasi dari 3 jenis mineral alterasi, yaitu Chlorite Sericite Zone (pgm), Secondary Feldspar (pot), dan Actinolite (act). Ketiga mineral alterasi ini memiliki rata-rata nilai suseptibilitas yang lebih tinggi dari mineral alterasi yang lain, seperti pada Tabel 1.
Tabel 1. Nilai suseptibilitas magnetik mineral alterasi dari 6 hole

\begin{tabular}{|c|c|c|}
\hline Alterasi & $\begin{array}{l}\text { Range Magsus } \\
\left(10^{-3} \mathrm{SI}\right)\end{array}$ & Rata-rata $\left(10^{-3}\right) \mathrm{SI}$ \\
\hline A (Argilic) & $0.13-825.67$ & 46.42 \\
\hline AA (Advance Argilic) & $0.24-15.81$ & 1.53 \\
\hline Act (actinolite) & $0.38-252.20$ & 90.39 \\
\hline Bio (Biotite) & $13.06-126.53$ & 78.98 \\
\hline Fd (Felspar Destructive) & $0.09-34.85$ & 0.92 \\
\hline Pgm (Chlorite Sericite Zone) & $0.19-1459$ & 101.26 \\
\hline Pgm_A (pgm Argilic) & $46.33-132.67$ & 83.88 \\
\hline Phy (Phyryte) & $0.29-38.50$ & 10.30 \\
\hline Pot (Secondary Feldspar) & $0.24-317.77$ & 104.01 \\
\hline Prop (Propilic) & $065-3.84$ & 2.14 \\
\hline Prop_A (Propilic Argilic) & $0.50-5.10$ & 1.81 \\
\hline Scc (Sericite Chlorte Clay) & $0.16-987.23$ & 41.91 \\
\hline Si (Massive Silicification) & $0.49-6.60$ & 3.20 \\
\hline Si_A (Silicification Argilic) & $0.08-1.08$ & 0.29 \\
\hline Si_Pgm (pgm silicification) & $0.42-43.27$ & 15.01 \\
\hline
\end{tabular}

Strip Log ROM-001 menunjukkan bahwa pgm, pot, dan act memiliki nilai suseptibilitas magnetik yang lebih tinggi daripada mineral lainnya (Gambar 16)

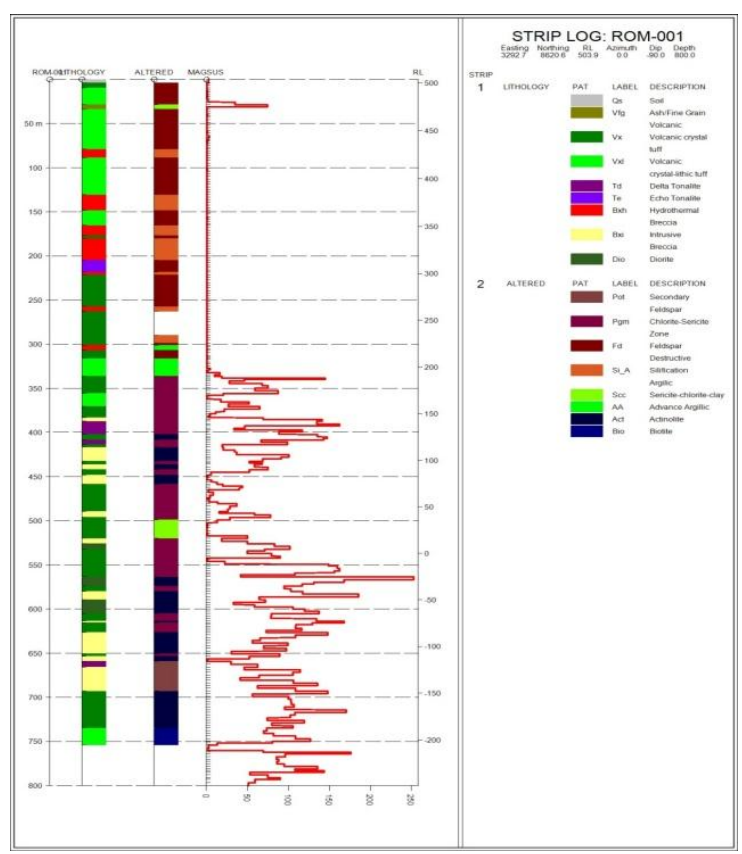

Gambar 16. Strip Log ROM-001 
Pada ROM-002, mineral alterasi dengan nilai suseptibilitas yang tinggi adalah pgm dan pot (Gambar 17).

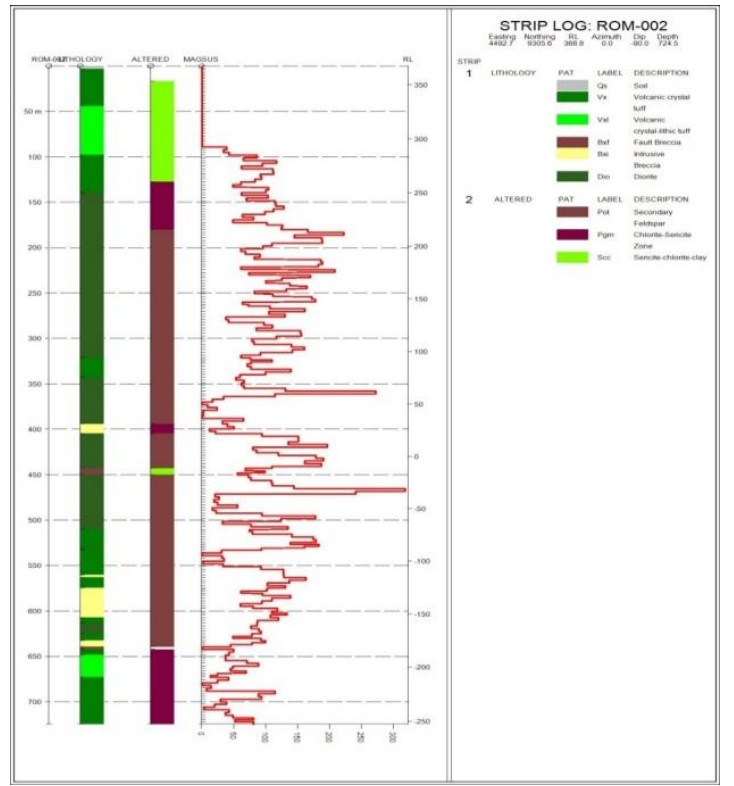

Gambar 17. Strip Log ROM-002

Mineral alterasi pgm, pot, dan act kembali dominan pada ROM-003, seperti pada Gambar 18.

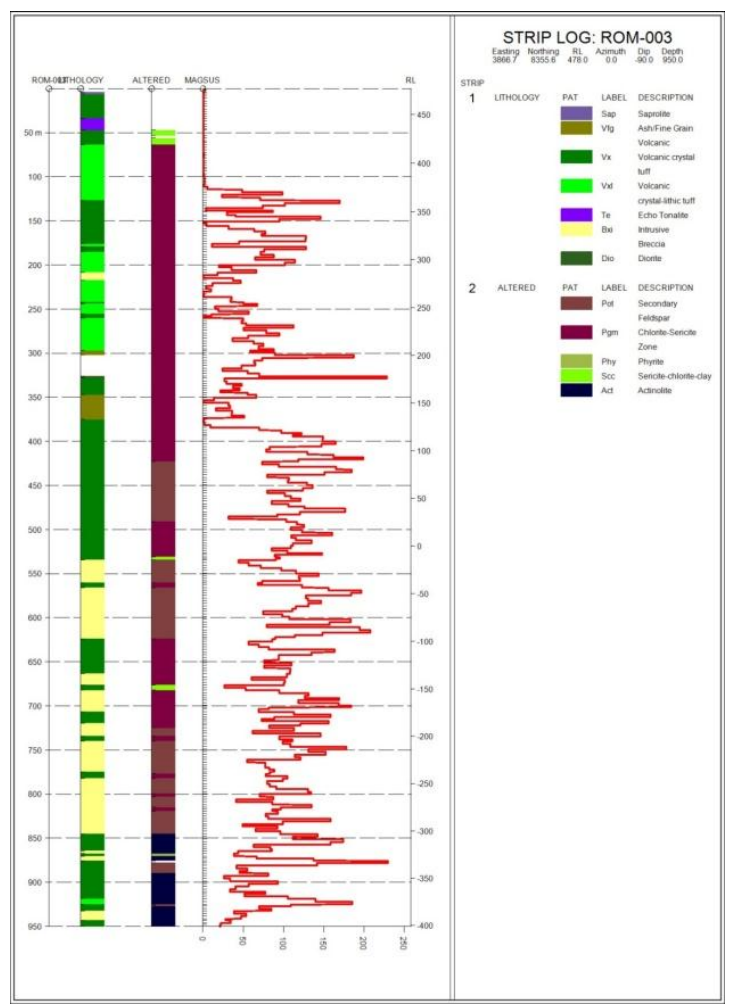

Gambar 18. Strip Log ROM-003
Demikian juga dengan ROM-004, mineral alterasi dengan rata-rata nilai suseptibilitas yang tinggi adalah pgm, pot, dan act (Gambar 19).

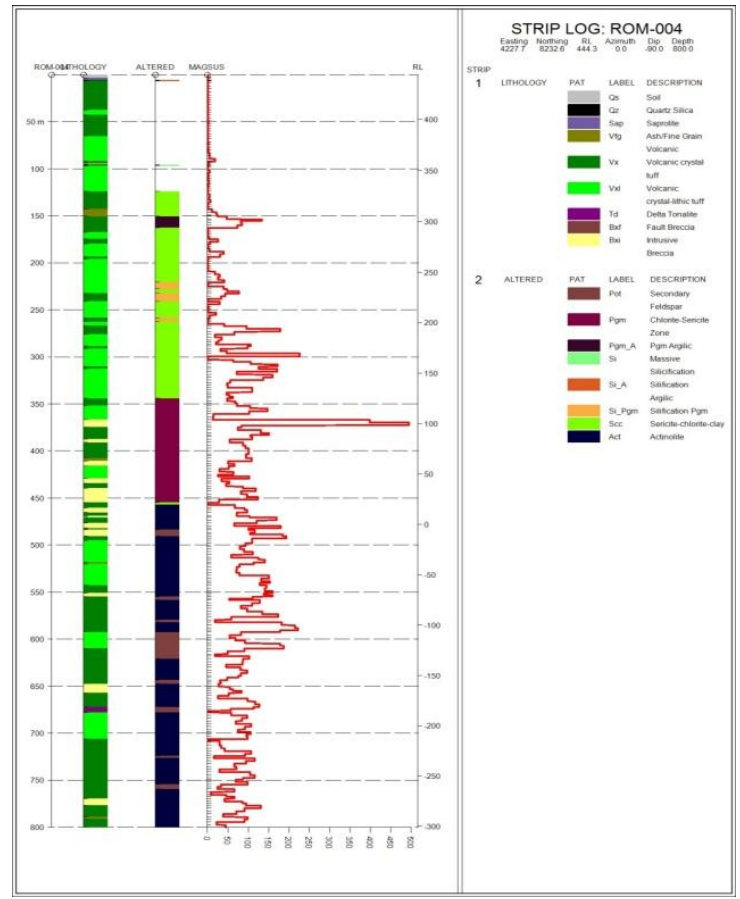

Gambar 19. Strip Log ROM 004

ROM-005 diperkirakan berada jauh diluar sistem porfiri. Hal ini ditunjukkan dengan rendahnya nilai suseptibilitas magnetik mineral penyusunnya (Gambar 20).

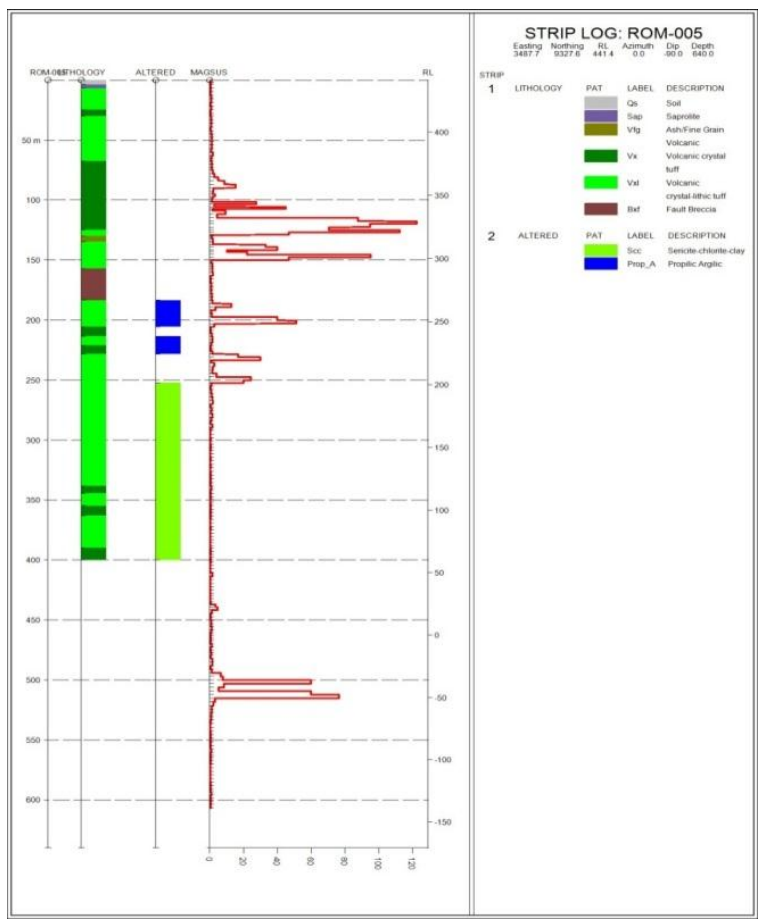

Gambar 20. Strip Log ROM-005 
ROM-006 merupakan hole yang memiliki nilai suseptibilitas yang tertinggi dibandingan dengan hole yang lain. Hai ini menunjukkan bahwa ROM-006 diperkirakan berada pada sistem porfiri. Mineral alterasi yang dominan pada hole ini adalah pgm, pot, dan act (Gambar 21).

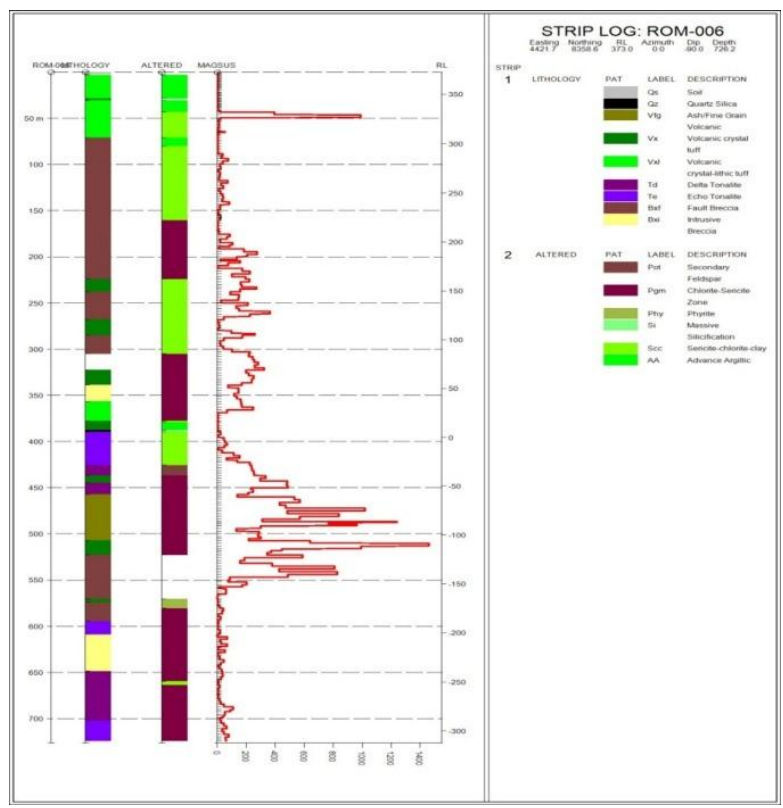

Gambar 21. Strip Log ROM-006

\section{Holes Correlation}

Jika semua hole disatukan dan dibuat korelasinya maka akan terlihat bahwa nilai suseptibilitas magnetik yang tinggi berada pada hole ROM-006. Hal ini menunjukkan bahwa posisi intrusi melalui hole ROM006 (Gambar 22).

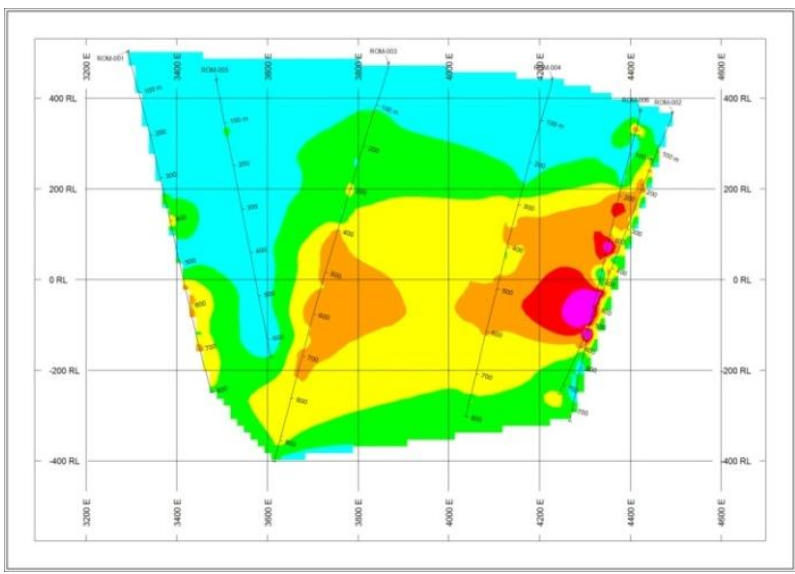

Gambar 22. Korelasi antara semua hole Posisi Intrusi

Intrusi batuan berhubungan erat dengan kemagnetan batuan. Intrusi batuan pada umumnya memiliki nilai kemagnetan yang lebih tinggi dibandingkan dengan daerah-daerah disekitarnya. Oleh karena itu, keberadaan dan posisi suatu intrusi bisa dianalisis berdasarkan nilai kemagnetan batuannya.

Berdasarkan nilai suseptibilitas magnetic yang diperoleh dari semua hole (ROM-001, ROM-002, ROM-003, ROM-004, ROM-005, dan ROM-006) diketahui bahwa nilai suseptibilitas magnetic yang tinggi berada di hole ROM-006 sehingga dapat diprediksi bahwa posisi intrusi melalui hole ROM-006 (Gambar 23 dan Gambar 24).

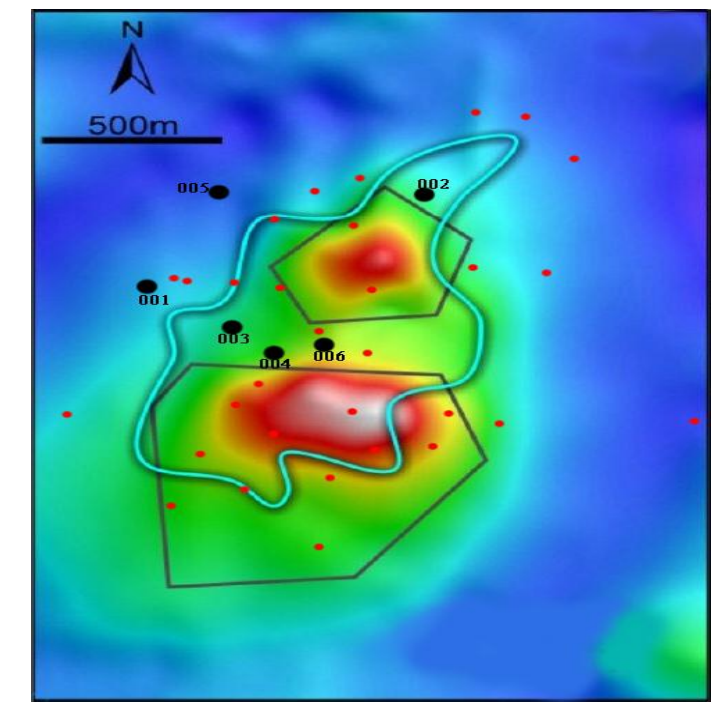

Gambar 23. Anomali magnetik dan posisi hole daerah Elang

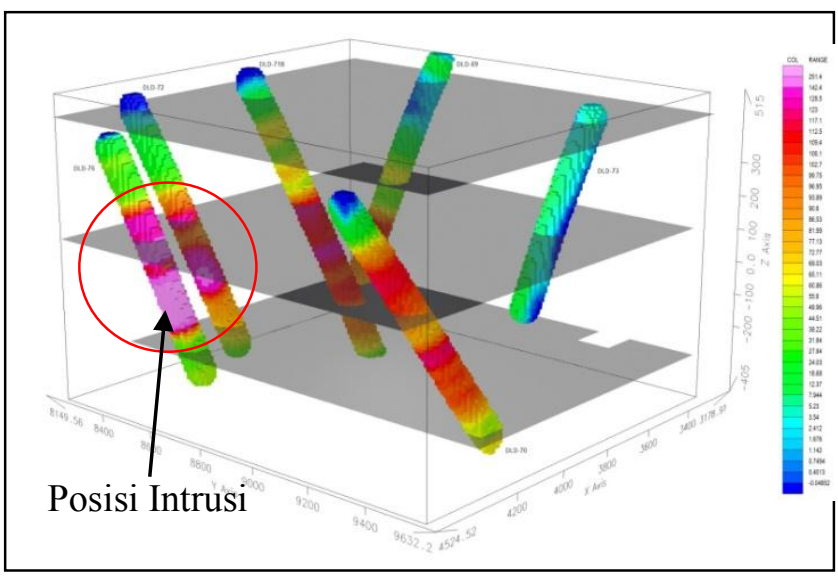

Gambar 24. Perkiraan posisi intrusi

\section{Penutup}

Berdasarkan hasil penelitian dan pengamatan didapat beberapa kesimpulan:

1. Alterasi Chlorite Sericite Zone (pgm), secondary Feldspar (pot), dan Actinolite (act) adalah alterasi 
yang mendominasi semua hole di daerah Elang dengan rata-rata nilai suseptibilitas magnetic yang tinggi, yaitu $\operatorname{pgm}\left(\kappa=0,19.10^{-3} \mathrm{SI}-1459.10^{-3} \mathrm{SI}\right.$ dan $\left.\bar{\kappa}=101,26 \cdot 10^{-3} \mathrm{SI}\right), \operatorname{pot}\left(\kappa=0,24 \cdot 10^{-3} \mathrm{SI}-317,77.10^{-}\right.$ ${ }^{3} \mathrm{SI}$ dan $\left.\bar{\kappa}=104,01 \cdot 10^{-3} \mathrm{SI}\right)$, Act $\left(\kappa=0,38 \cdot 10^{-3} \mathrm{SI}-\right.$ $252,2 \cdot 10^{-3}$ SI dan $\left.\bar{\kappa}=90,39 \cdot 10^{-3} \mathrm{SI}\right)$.

2. Rata-rata nilai suseptibilitas magnetic paling besar berada pada hole ROM-006 sehingga dapat diperkirakan posisi intrusi melalui hole ROM-006.

\section{REFERENSI}

[1] Ball, R. 2011. Newmont Mining Corporation Presentation, CIBC Annual Instutional Investor Conference, Whistler, B.C.

[2] Clark D.A. dan Emerson D.W. 1991. Notes on rock magnetization characteristics in applied geophysical studies. Exploration Geophysics Vol. 22

[3] Hoschke, T. 2011. Geophysical Signatures of Copper-Gold Porphyry and Epithermal gold deposits, and implications for exploration. Australia: University of Tasmania.

[4] Hoschke, T. 2012. Geophysics of the Elang $\mathrm{Cu}-\mathrm{Au}$ Porphyry Deposit, Indonesia, and Comparison with other $\mathrm{Cu}-\mathrm{Au}$ Porphyry System. Australia: Newmont Asia Pasific.

[5] Jahidin, Ngkoimani L.O, dan Bijaksana S. 2011. Analisis Suseptibilitas Magnetik Batuan Ultrabasa di Desa Mosolo Pulai Wawonii Provinsi Sulawesi Tenggara. Bandung : ITB

[6] Kahfi RA. dan Yulianto T. 2008. Identifikasi Struktur Lapisan BAwah Permukaan Daerah Manifestasi Emas dengan Meggunakan Metode Magnetik di Papandayan Garut Jawa Barat. Semarang: Universitas Diponegoro.

[7] Lubis H., Maryono A., Perdanakusumah A., dan Hermawan W. 2006. The Elang Porphyry Copper and Gold Mineralization Style Sumbawa Indonesia. Sumbawa: PT. NNT

[8] Whitehead, N. 2006. Montaj Drillhole Plotting Tutorial. Toronto: Geosolf Inc. 